\title{
New mutations in the PKDI gene in Czech population with autosomal dominant polycystic kidney disease
} Jitka Stekrova*1, Jana Reiterova ${ }^{1,2}$, Stanislava Svobodova ${ }^{1}$, Vera Kebrdlova ${ }^{1}$,
Petr Lnenicka $^{1}$, Miroslav Merta ${ }^{2}$, Ondrej Viklicky ${ }^{2,3}$ and Milada Kohoutova ${ }^{1}$

Address: ${ }^{1}$ Institute of Biology and Medical Genetics of the 1st Faculty of Medicine and General Teaching Hospital, Charles University, Albertov 4 , Prague 2, 128 00, Czech Republic, ${ }^{2}$ Department of Nephrology of the 1st Faculty of Medicine and General Teaching Hospital, Charles University, U Nemocnice 2, Prague 2, 128 00, Czech Republic and 3Institute of Clinical and Experimental Medicine, Videnska 1958, Prague 4, 140 00, Czech Republic

Email: Jitka Stekrova* - jstek@If1.cuni.cz; Jana Reiterova - jreiterova@seznam.cz; Stanislava Svobodova - mmakulka@yahoo.com; Vera Kebrdlova - vkebr@lf1.cuni.cz; Petr Lnenicka - petr.lnenicka@vfn.cz; Miroslav Merta - merta@cesnet.cz; Ondrej Viklicky - onvi@medicon.cz; Milada Kohoutova - mkoho@lf1.cuni.cz

* Corresponding author

Published: 17 August 2009

BMC Medical Genetics 2009, 10:78 doi:10.1186/1471-2350-10-78
Received: 14 October 2008

Accepted: 17 August 2009

This article is available from: http://www.biomedcentral.com/I47I-2350/I0/78

(c) 2009 Stekrova et al; licensee BioMed Central Ltd.

This is an Open Access article distributed under the terms of the Creative Commons Attribution License (http://creativecommons.org/licenses/by/2.0), which permits unrestricted use, distribution, and reproduction in any medium, provided the original work is properly cited.

\begin{abstract}
Background: Autosomal dominant polycystic kidney disease (ADPKD) is the most common hereditary renal disease. The disease is caused by mutations of the PKDI (affecting roughly $85 \%$ of ADPKD patients) and PKD2 (affecting roughly I 4\% of ADPKD patients) genes, although in several ADPKD families, the PKDI and/or PKD2 linkage was not found. Mutation analysis of the PKDI gene is complicated by the presence of highly homologous genomic duplications of the first two thirds of the gene.
\end{abstract}

Methods: The direct detection of mutations in the non-duplicated region of the PKDI gene was performed in 90 unrelated individuals, consisting of 58 patients with end-stage renal failure (manifesting before their $50^{\text {th }}$ year of life) and 32 individuals from families where the disease was clearly linked to the PKDI gene. Mutation screening was performed using denaturing gradient gel electrophoresis (DGGE). DNA fragments showing an aberrant electrophoretic banding pattern were sequenced.

Results: In the non-duplicated region of the PKDI gene, 19 different likely pathogenic germline sequence changes were identified in 19 unrelated families/individuals. Fifteen likely pathogenic sequence changes are unique for the Czech population. The following probable mutations were identified: 9 nonsense mutations, 6 likely pathogenic missense mutations, 2 frameshifting mutations, one in-frame deletion and probable splice site mutation. In the non-duplicated region of the PKDI gene, 16 different polymorphisms or unclassified variants were detected.

Conclusion: Twenty probable mutations of the PKDI gene in 90 Czech individuals (fifteen new probable mutations) were detected. The establishment of localization and the type of causal mutations and their genotype phenotype correlation in ADPKD families will improve DNA diagnosis and could help in the assessment of the clinical prognosis of ADPKD patients. 


\section{Background}

ADPKD is the most frequently inherited renal cystic disorder with an incidence between 1 in 400 to 1 in 1000 [1]. ADPKD is a systemic disorder with cysts and connective tissue abnormalities involving many organs [2]. The progressive formation and enlargement of renal cysts causes the decline in renal function.

The disease is genetically heterogeneous. At least three different genes are involved. The PKD1 locus (MIM 601313) is linked to the short arm of chromosome 16, at 16p13.3 $[3,4]$; and so far, 818 different sequence variants have been reported in Polycystic Kidney Disease Mutation Database (PKDB) [5]. Later, a second locus PKD2 (MIM 173910) was located on chromosome 4q21 [6]; and 123 different sequence variants have been reported in PKDB [5]. Families with ADPKD unlinked to the PKD1 or PKD2 loci have also been described [7], but the predicted PKD3 locus (MIM 600666) has not been mapped yet. Eightyfive percent of ADPKD cases are caused by a mutation of the PKD1 gene on chromosome 16 and in about $15 \%$ of all cases, the PKD2 gene on chromosome 4 is mutated [8]. When PKD2 patients are compared to PKD1 patients, they seem to have a milder clinical presentation. The average age of PKD1 patients at end-stage renal disease (ESRD) is 54.3 years compared with 74.0 years for PKD2 patients [9].

The PKD1 gene consists of 46 exons from which a $14.1 \mathrm{~kb}$ transcript is produced. The 4303-aminoacid product of PKD1 is called polycystin-1. The PKD2 gene consists of 15 exons. The $5.4 \mathrm{~kb}$ PKD2 transcript encodes the protein polycystin-2, which consists of 968 amino acids. Polycystin-2 is a TRP (transient receptor potential) ion channel, which is involved in regulation of intracellular $\mathrm{Ca}^{2+}$ concentration [10]. The cytoplasmic $\mathrm{COOH}$ terminus of polycystin-2 interacts with the coiled-coil region of polycystin$1[11,12]$. Both polycystins, similarly to other cystogenic proteins, have been localized to primary cilia [13]. This complex may act as a flow-dependent mechanosensor that regulates the differentiated state of tubular epithelial cells [14].

ADPKD is the disease with variable clinical course not only among families with different mutations, but within families with a defined mutation as well. Different mutations in PKD genes may have different effects on the clinical course of the disease. The genotype-phenotype correlation of 80 families revealed earlier ESRD (49 years versus 54 years) for mutations in the 5 'region of the PKD1 gene (to exon 19, nucleotide 7812) in comparison with mutations in the 3'region [15]. Very early onset of the ESRD has been described in families with mutations in exons 15 and 41 of the PKD1 gene $[16,17]$. As for PKD2 patients, those mutations at the 3 'end of the PKD2 gene result in a milder clinical course; however there is no clear correlation between the age of onset of ESRD and the location or the type of mutation [18]. The majority of PKD1 and PKD2 mutations are unique to a single family, recurrent mutations account only for $30 \%$ of the total. Detection levels are from 60 to $70 \%$ [19]. In this study, the nonduplicated region of the PKD1 gene in 90 unrelated Czech individuals was screened.

\section{Methods \\ Patients}

The coding sequences of the non-duplicated region of the PKD1 gene in 90 unrelated Czech patients with ADPKD were screened. The study was performed with the approval of the Ethics Committee of the General Teaching Hospital in Prague. Informed consent was obtained from each patient before genetic testing. Fifty-eight ADPKD patients (hemodialysis-HD 158) from dialysis centres in the Czech Republic, from the Transplantation Centre in Prague and from the Department of Nephrology of the General University Hospital in Prague were selected. This group (34 males, 24 females) that reached ESRD were all aged between 33 and 50 (average age at onset of ESRD is $44.5 \pm 4.8$ years). Other 32 unrelated patients ( 18 males, 14 females) with ADPKD clearly linked to the PKD1 gene, according to the linkage analysis in Czech families, were selected (data not shown).

Asymptomatic at-risk individuals were examined by ultrasound. The positive diagnosis of ADPKD was based upon the criteria described by Ravine [20]. In most patients, the onset of arterial hypertension was established retrospectively. Hypertension was defined as a blood pressure higher than 140/90 $\mathrm{mmHg}$ (repeatedly measured) or a normal blood pressure maintained by the use of antihypertensive drugs.

\section{Mutational screening}

Genomic DNA was isolated from peripheral blood lymphocytes by the salting-out procedure [21]. The coding region and intron-exon boundaries of the non-duplicated region of the PKD1 gene were screened for mutations using Denaturing Gradient Gel Electrophoresis (DGGE). Exons 3446 were amplified using the set of GC-clamped primers. Sequences of primers, PCR and DGGE conditions are described in detail by Perrichot et al. [22]. All PCR fragments showing an aberrant electrophoretic banding pattern on DGGE were sequenced in both directions using an automatic fluorescent genetic analyzer (ABI Prism $^{\mathrm{TM}} 310$ Genetic Analyzer; PE Applied Biosystems) in accordance with the manufacturer's instructions. To prove the segregation of the potential mutation with the disease in the family, the DNAs of all available members of the concrete family were analyzed using DGGE (Figure 1a) and/or sequencing. 
a

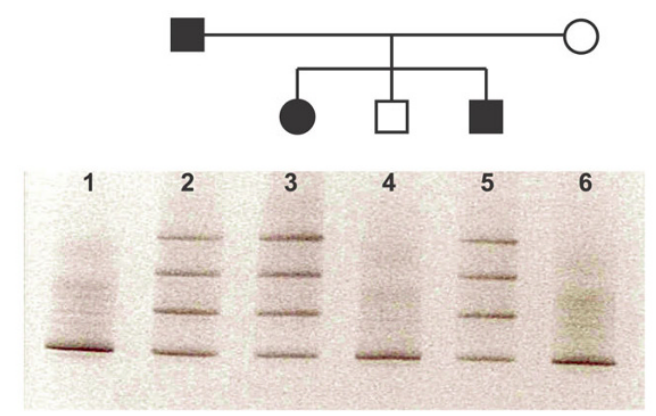

b

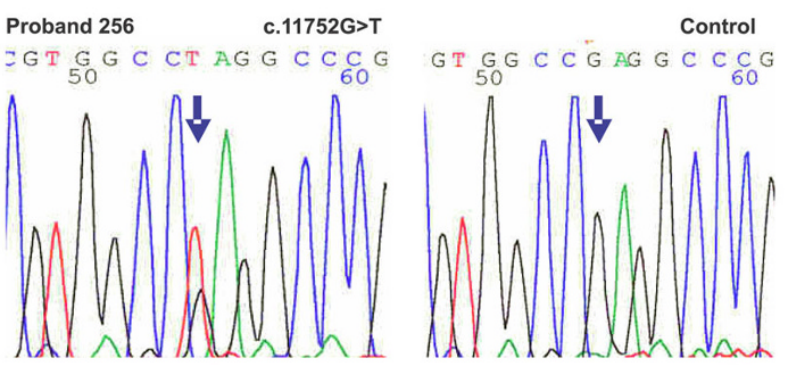

Figure I

The segregation of the PKDI germline mutation p.E39 I $8 X$ with the disease in family 256. a. Denaturing Gradient Gel Electrophoresis of PCR products of part A of exon 43 of the family 256. Lane I represents control. Lanes 2, 3 and 5 represent heterozygous affected members of the family. Lanes 4 and 6 represent healthy members of the family. b. Sequencing pattern of part of the exon 43 (forward) in proband of the family 256 with heterozygous substitution G>T at nucleotide position I I752 of the PKD / gene (p.E39l8X) and control.

In the case of not-yet described missense mutations, 200 healthy individuals were tested for the presence of this potential mutation. This test was performed by restriction analysis (in case that the restriction site is created or abolished as a consequence of the found sequence change), high resolution melting analysis (HRM; LightCycler ${ }^{\circledR} 480$ Roche instrumentation) or SNaPshot ${ }^{\mathrm{TM}}$ Multiplex Kit (ABI PRISM $^{310}$ instrumentation) according to the manufacturer's instructions.

\section{Data analysis}

Putative missense changes in PKD1 gene were analyzed for their site conservation in protein sequences BLAST [23]. Multiple sequence alignment of protein sequences and the graphic view of the alignment were performed using BioEdit Sequence Alignment Editor (Figure 2) [24]. The position of a resultant amino acid change within polycystin-1 was determined at UniProtKB/Swiss-Prot entry P98161[25].

\section{Results and discussion}

Twenty (19 different) germline likely pathogenic sequence changes in 90 unrelated patients were identified by mutation analysis of the coding non-duplicated region of the PKD1 gene (Table 1). In one individual, two different likely pathogenic sequence changes were detected. Overall detection rate was $21.1 \%$ (19 out of 90 unrelated Czech patients), which is relatively high level considering that only non-duplicated region of the gene was screened. The high detection level of putative mutations confirms that DGGE is a reliable and sensitive (but time consuming) method for screening of mutations. It allows the resolution of relatively large DNA fragments, up to $500 \mathrm{bp}$. It is also capable to detect up to $100 \%$ of all single base substitutions. It has been shown to be more sensitive than many other commonly used mutation detection methods, including single strand conformation polymorphism (SSCP) and heteroduplex analysis [26]. DGGE has a number of limitations, including the use of specialized equipment, the addition of GC clamps (that makes the purchase of PCR primers expensive) and the knowledge of melting behavior for an efficient analysis.

Fifteen new likely pathogenic sequence changes in Czech population were identified. Twelve likely pathogenic sequence changes in 11 patients from 58 individuals (19.0\%), who had reached ESRD before the age of 50 years, were found. Eight putative mutations in 32 families $(25.0 \%)$ with clear linkage to the PKD1 gene were identified. Ten nonsense mutations $(50.0 \%)$, six likely missense mutations $(30.0 \%)$, two frameshifting mutations $(10.0 \%)$, one in-frame deletion $(5.0 \%)$ and one putative splice site mutation (5.0\%) were identified in total. In the non-duplicated region of the PKD1 gene, sixteen different polymorphisms were also described (Table 2).

Clinical characteristics of patients/probands with an identified putative mutation are summarized in Table 3.

Nonsense mutations in the PKD1 gene were the most frequent sequence changes in our patients. They were detected in $50.0 \%$ of affected individuals. Two short deletions in two patients (HD 2, HD 41) and one insertion/ duplication (HD 12) were detected. Truncating mutations were found in $70.0 \%$ of cases (including in-frame deletion and putative splice site mutation), which is in concordance with previous reports using other methods of detection, such as DHPLC or direct sequencing [19].

The nonsense mutation p.R4021X was found in two unrelated Czech patients (fam. 281, HD 31). This nonsense mutation was frequently detected in other studies [19,27]. These $\mathrm{C} \rightarrow \mathrm{T}$ change in CpG dinucleotides may be recurrent. Recurrent mutations account for 30\% of affected families and may simplify molecular diagnostics. The clinical course was quite severe in both Czech families. All 
family members from the hemodialyzed patient (HD 31), who had renal failure at the age of 36 years, were examined. Four of his siblings had renal failure at the ages of $54,40,43$, and 42 years. Two affected sisters from family 281 had renal failure at the age of 50 years with manifestation and complications of the disease (such as severe hypertension, urolithiasis and recurrent cyst infections) from 30 years of age.

A short deletion of 6 bases c.11340_11345delTTACGA is an in-frame putative mutation which ends in the absence of two amino acids p.Y3781_D3782del (Figure 3a). The proband already had ESRD at the age of 42 years. This deletion is in the area of frequent mutations/polymorphisms (Figure 3). The deletion was not present in the 27 year-old son with normal ultrasound. The deletion was present in the 29 year-old son who already suffered from mild renal insufficiency (serum creatinine $150 \mu \mathrm{mol} / \mathrm{l}$ ). We would have predicted a milder clinical course in these two patients with ADPKD; however, both of them did not regularly use antihypertensive drugs and so did suffer from severe hypertension.

The deletion of 22 bases c.11623_11645del22 (p.A3875PfsX62) in exon 42 was detected in the patient with ESRD at the age of 44 years. This frameshift mutation leads to the formation of 62 new amino acids and then to a shorter protein.

The duplication of 8 bases c.11345dupGATTACGA (p.D3782EfsX46) (Figure 3b) in exon 40 was identified in the patient with ESRD at the age of 45 years. This change is also in the area of frequent mutations/polymorphisms (Figure 3). After 46 new amino acids, the protein is terminated.

The substitution in intron 36 (c.10821+1G $\rightarrow$ C) in the patient with ESRD at the age of 45 years (HD 15) was identified. This change is located just in the conserved donor splice site and will probably lead to an abnormal splicing. No mRNA experiment was available in our laboratory to confirm this hypothesis, but it has been well demonstrated in other genes. The effect of this substitution could be predicted either as exon skipping (in this case the skipping of exon 36) or frameshift [19,28]. This probable splice site mutation in intron 36 was also found in the 27 year-old son of the proband with enlarged cystic kidneys upon ultrasound, but was missing in two other sons of the proband (30 and 26 years-old) with normal ultrasounds. The causality of this substitution is thus highly probable. In addition, another substitution c.11080C $\rightarrow$ T (p.C3694R) in exon 38 was identified in

\begin{tabular}{|c|c|c|c|c|}
\hline & p.L3617P & $\begin{array}{l}\text { p.S3693L } \\
\text { p.C3694R }\end{array}$ & p.Q4216H & p.R4228P \\
\hline & $\downarrow$ & & $\downarrow$ & $\downarrow$ \\
\hline Human & ALYFSLVAKRLHPDE & LLASYGDASCHGH - - & EPEPSRLQAVFEALL & LLTQFDRLNQATEDV \\
\hline Canis familiaris & ALYFSLVAKRLHPDE & LLANHGDASCHNH - - & EPEPSRLQAVFEALL & LLTQFDRLNQATEDV \\
\hline Mus musculus & ALYFSLVAKRLHPDE & LLANYGDASCHGH - - & EPEPSRLHAVFESLL & LLVQFDRLNQATEDV \\
\hline Gallus gallus & ALYFSLVAKRLHPEE & LLTNYGDATRNSR-- & DADLQRLLSLFEMLL & LLAQFDRVNQVTEDV \\
\hline Xenopus laevis & ALYFALVVKRLHPEE & LITNYGEAPKNNN-- & -ー-ー-ー-ー-ー-ー-- & 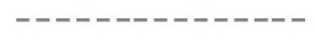 \\
\hline Takifugu rubripes & AVYYAVYVRRLRPED & LLLNYSDSDKDAH - - & EASLRRLLPTLDALL & LLQQLDRVTVATEDL \\
\hline Amphioxus & ALFLASISKPTNHDD & LI IAFNDNDLNTYRM & EYLLDRLTPTVDAVL & VLSTFDRLRHYVDDD \\
\hline Echinoid & AAFSAVIWKKHEDDD & LEVAHFQRD PNNY - - & 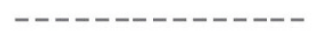 & 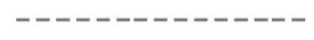 \\
\hline Sea anemone & GSSLFQCSTMLN--- & LNDAYEDVNTNTD-- & 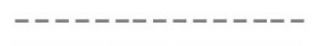 & 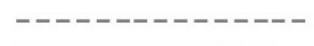 \\
\hline Placozoa & AFIFALIVRRPDLGV & ILICYGNRDSNAYYQ & HRRYTIVQNQLDDIL & ILVCVNRINAKRK-- \\
\hline
\end{tabular}

\section{Figure 2}

The graphic alignment of putative causal missense mutations in PKDI gene. Multiple sequence alignment of protein sequences was performed with distant species: Human sp|P98I6I-3|PKDI_HUMAN Isoform 3 of Polycystin-I; Canis lupus familiaris ref|NP_00100665I.I| polycystin I; Mus musculus ref|NP_038658.2| polycystin I; Gallus gallus ref|XP_4I4854.2| PREDICTED: similar to polycystin I; Xenopus laevis gb|AAT77543.I| polycystic kidney disease protein I precursor; Takifugu rubripes gb|AAB86683.I| unknown; Amphioxus Branchiostoma floridae ref|XP_0022024I3.I| hypothetical protein BRAFLDRAFT_648I0; Echinoid Strongylocentrotus purpuratus ref|XP_00 I 19483 I.I| PREDICTED: similar to receptor for egg jelly 4;Sea anemone Nematostella vectensis ref|XP_001640030.I| predicted protein; Placozoa Trichoplax adhaerens ref|XP_002I I 0052.I| hypothetical protein TRIADDRAFT_53596. The positions of putative missense mutations are marked by red arrows. 
Table I: Likely pathogenic sequence changes identified in the non-duplicated region of the PKDI gene in Czech patients with ADPKD

\begin{tabular}{|c|c|c|c|c|}
\hline Family & Exon/Intron & Nucleotide change & $\begin{array}{l}\text { Aminoacid changel } \\
\text { Predicted effect }\end{array}$ & Reference \\
\hline HD 53 & 34 & c. 10462 C>T & p.Q3488X & Current paper \\
\hline HD I5 & IVS36 & c. $|082|+\mid G>C$ & probably splice defect & Current paper \\
\hline 340 & 37 & c. $10850 \mathrm{~T}>\mathrm{C}$ & p.L36 I7P (Fig. 2) & Current paper \\
\hline 173 & 38 & c. $11078 \mathrm{C}>\mathrm{T}$ & p.S3693L (Fig. 2) & Current paper \\
\hline HD I5 & 38 & c. I I $080 \mathrm{~T}>\mathrm{C}$ & p.C3694R (Fig. 2) & Current paper \\
\hline 329 & 39 & c. II $258 \mathrm{G}>\mathrm{A}$ & p.R3753Q & {$[19]$} \\
\hline HD 2 & 40 & c.I1340_II345 delTTACGA & p.Y378I_D3782del (Fig. 3a) & Current paper \\
\hline HD I 2 & 40 & c. I I345dup8 & p.D3782EfsX46 (Fig. 3b) & Current paper \\
\hline HD 23 & 41 & c. 11417 G>A & p.W3806X & Current paper \\
\hline HD 41 & 42 & c.11623_II645del22 & p.A3875Pfs X62 & Current paper \\
\hline 256 & 43 & c. II752 G>T & p.E39 I 8X (Fig. I) & Current paper \\
\hline HD 10 & 44 & c. $|203| \mathrm{C}>\mathrm{T}$ & P.Q40IIX & [29] \\
\hline 323 & 44 & c. $\mid 2056 \mathrm{~T}>\mathrm{G}$ & p.L4019X & Current paper \\
\hline 281 & 44 & c. $|206| \mathrm{C}>\mathrm{T}$ & p.R402IX & {$[27]$} \\
\hline HD 31 & 44 & c. $|206| \mathrm{C}>\mathrm{T}$ & p.R402IX & [27] \\
\hline 387 & 44 & c. $12124 \mathrm{C}>\mathrm{T}$ & P.Q4042X & {$[27]$} \\
\hline 237 & 46 & c. I $2648 \mathrm{~A}>\mathrm{C}$ & p.Q42 I 6H (Fig. 2) & Current paper \\
\hline HD 38 & 46 & c. $\mid 2683$ G>C & p.R4228P (Fig. 2) & Current paper \\
\hline HD I & 46 & c. $|269| \mathrm{C}>\mathrm{T}$ & p.Q423IX & Current paper \\
\hline HD 40 & 46 & c. $12724 \mathrm{C}>\mathrm{T}$ & p.Q4242X & Current paper \\
\hline
\end{tabular}

Novel probable mutations in boldface type. HD patients from dialysis centres in Czech Republic, IVS the intronic sequence; Current paper mutation was not described in The Polycystic Kidney Disease Mutation Database (PKDB server) [5] and/or in The Human Gene Mutation Database at the Institute of medical Genetics in Cardiff $\left(\mathrm{HGMD}^{\circledR}\right.$ server) [30].

the same family. The level of conservation of this missense variant is relatively low, though it is conserved well in mammals (Figure 2). Moreover, it segregates with the affected individuals in the family and is not present in 200 unrelated healthy controls. This missense variant in exon 38 can eventually contribute to the expansion of the severe clinical course of ADPDK as well and intensify the negative effect of probable splice site mutation in intron 36 on the function of polycystin-1. We can thus only speculate, which of these two substitutions is really causative.
Together with the potential missense mutation c.11080C $\rightarrow$ T (p.C3694R) in exon 38, six putative missense mutations in ADPKD patients (30.0\% of all mutations) were detected. The most important factor in determining whether a missense change was likely pathogenic was the degree to which the corresponding sequence of amino acids was conserved. All missense variants segregated with affected members within a family. Moreover, 200 unrelated healthy individuals were tested and no similar changes were observed. 
Table 2: Polymorphisms identified in the non-duplicated region of the PKDI gene in Czech patients with ADPKD

\begin{tabular}{|c|c|c|c|c|}
\hline Allele frequency & Exon/Intron & Nucleotide change & $\begin{array}{l}\text { Aminoacid change/ } \\
\text { Predicted effect }\end{array}$ & Reference \\
\hline $3.3 \%$ & 35 & c. $10529 \mathrm{C}>\mathrm{T}$ & p.T35I0M & {$[31]$} \\
\hline $20.0 \%$ & 35 & c. $10535 \mathrm{C}>\mathrm{T}$ & p.A35I2V & {$[32]$} \\
\hline $4.4 \%$ & 36 & c. $10768 \mathrm{C}>\mathrm{T}$ & p.L3590L & {$[33]$} \\
\hline $1.1 \%$ & IVS38 & c. $11156+13 \mathrm{G}>\mathrm{A}$ & Likely silent & {$[22]$} \\
\hline $1.1 \%$ & 40 & c. $11346 \mathrm{C}>\mathrm{T}$ & p.A3782A (Fig. 3c) & {$[34]$} \\
\hline $2.2 \%$ & IVS4I & c. $11537+5+6$ insGGG & Likely silent & {$[35]$} \\
\hline $2.2 \%$ & IVS43 & c. $12004-34 \mathrm{C}>\mathrm{A}$ & Likely silent & [29] \\
\hline $17.8 \%$ & 44 & c. $12133 \mathrm{~A}>\mathrm{G}$ & p. $14045 \mathrm{~V}$ & [36] \\
\hline $3.3 \%$ & IVS44 & c. $12138+22$ delG & Likely silent & [37] \\
\hline $8.9 \%$ & 45 & c. $12176 \mathrm{C}>\mathrm{T}$ & p.A4059V & [36] \\
\hline $1.1 \%$ & 45 & c. $12270 \mathrm{C}>\mathrm{G}$ & p.L4090L & {$[38]$} \\
\hline $12.2 \%$ & 45 & c. 12276 A $>G$ & p.A4092A & [39] \\
\hline $10.0 \%$ & 45 & c. 12409 C>T & p.L4I37L & [39] \\
\hline $1.1 \%$ & 45 & c. 12436 G>A & p.V4|46I & [39] \\
\hline $17.8 \%$ & 46 & c. $12630 \mathrm{~T}>\mathrm{C}$ & p.P42IOP & {$[40]$} \\
\hline $2.2 \%$ & 46 & c. I $2666 \mathrm{C}>\mathrm{T}$ & p.L4222L & Current \\
\hline
\end{tabular}

cDNA numbering is based on reference database: The Polycystic Kidney Disease Mutation Database (PKDB server) [5].

Novel polymorphisms in boldface type. IVS the intronic sequence; Current paper mutation was not described in The Polycystic Kidney Disease Mutation Database (PKDB server) [5] and/or in The Human Gene Mutation Database at the Institute of medical Genetics in Cardiff (HGMD ${ }^{\circledR}$ server) [30].

The putative missense mutation c.10850 $\mathrm{T} \rightarrow \mathrm{C}$ (p.L3617P) in exon 37 was identified in the family 340. This missense variant was present in the proband with enlarged cystic kidneys, in his son (multiple cysts at the age of 30 years) and in his daughter (two renal cysts at the age of 10 years). Leucine (a neutral hydrophobic amino acid) was changed to proline (which has an aliphatic side chain unlike other amino acids). Leucine in this position is conserved in all mammals, xenopus and trichoplax studied (Figure 2).

The putative missense mutation c. $11078 \mathrm{C} \rightarrow \mathrm{T}$ (S3693L; family 173) leads to the change of serine (a neutral hydrophilic amino acid) into leucine (a neutral hydrophobic amino acid). Serine is conserved only in mammals (Figure 2). This substitution was present in the proband (normal serum creatinine at the age of 38 years, enlarged cystic kidneys on ultrasound), in his mother (with ESRD at the age of 55 years, severe hypertension) and in his 7 year-old daughter (two renal cysts on ultrasound). This substitution was not present in the brother (normal ultrasound at the age of 40 years) and in the son (normal ultrasound at the age 12 year) of the proband.

The putative missense mutation c.11258 G $\rightarrow$ A (p.R3753Q) in exon 39 was identified in the family 329. Arginine (a basic amino acid) was changed to glutamine (a neutral amino acid containing an amino and an amide group). The grandfather of the proband had ESRD at the age of 59 years, the 58 year-old female suffered from moderate renal insufficiency (serum creatinine $220 \mu \mathrm{mol} / \mathrm{l}$ ). The 32 year-old female was diagnosed by ultrasound at 
Table 3: Clinical characteristics of patients/probands with identified likely pathogenic mutation

\begin{tabular}{|c|c|c|c|c|}
\hline Patient/Proband & $\begin{array}{l}\text { Likely pathogenic } \\
\text { sequence changes }\end{array}$ & $\begin{array}{l}\text { Gender } \\
\text { F/M }\end{array}$ & $\begin{array}{l}\text { Age of ESRD (years) } \\
\text { Creatinine }(\mu \mathrm{mol} / \mathrm{l})\end{array}$ & $\begin{array}{l}\text { HT } \\
\text { Y/N }\end{array}$ \\
\hline HD 53 & P.Q3488X & $\mathrm{F}$ & 48 & $Y$ \\
\hline HD I5 & $\begin{array}{l}\text { Splice (c. }|082|+\mid G>C) \\
\text { and p.C3694R }\end{array}$ & $\mathrm{F}$ & 45 & $Y$ \\
\hline Fam.340 & p.L36I7P & $\mathrm{F}$ & 52 y- creat. 350 & $\mathrm{~N}$ \\
\hline Fam. 173 & p.S3693L & $F$ & 55 & $Y$ \\
\hline Fam.329 & p.R3753Q & $\mathrm{F}$ & 58 y- creat. 230 & $\mathrm{~N}$ \\
\hline HD 2 & p.Y378I_D3782del & $M$ & 42 & $Y$ \\
\hline $\mathrm{HD} 12$ & p.D3782EfsX46 & $M$ & 45 & $Y$ \\
\hline HD 23 & p.W3806X & $\mathrm{F}$ & 42 & $Y$ \\
\hline HD 4I & p.A3875PfsX62 & $\mathrm{F}$ & 44 & $Y$ \\
\hline Fam. 256 & p.E3918X & $\mathrm{F}$ & 50 & $\mathrm{~N}$ \\
\hline HD 10 & p.Q40IIX & $\mathrm{F}$ & 48 & $Y$ \\
\hline Fam. 323 & p.L40I9X & $M$ & $50 y$ - creat. 104 & $Y$ \\
\hline Fam. 28I & p.R402IX & $\mathrm{F}$ & 50 & $Y$ \\
\hline HD 31 & p.R402IX & $M$ & 36 & $Y$ \\
\hline Fam.387 & p.Q4042X & $M$ & 32 y- creat. 154 & $Y$ \\
\hline Fam. 237 & p.Q4216H & $\mathrm{F}$ & 42 & $Y$ \\
\hline HD 38 & p.R4228P & $M$ & 47 & $Y$ \\
\hline HD I & p.Q423IX & $\mathrm{F}$ & 50 & $Y$ \\
\hline HD 40 & p.Q4242X & $\mathrm{F}$ & 50 & $Y$ \\
\hline
\end{tabular}

cDNA numbering is based on reference database: The Polycystic Kidney Disease Mutation Database (PKDB server) [5].

$H D$ patients from dialysis centres in Czech Republic, $F$ female, $M$ male, HT Hypertension, $Y$ yes, $N$ no;

the age of 8 years and suffered from severe hypertension and from complicated renal infections. This putative missense mutation was described in another report [19].

The putative missense mutation c. $12648 \mathrm{~A} \rightarrow \mathrm{C}$ (p.Q4216H) in exon 46 was identified in the family 237. Glutamine (a neutral amino acid containing an amino and an amide group) was changed to histidine (a basic amino acid with an imidazole ring, which is frequently found in the reactive centre of proteins). Glutamine in this position was found in only a small portion of those mammals that have been compared (Figure 2). The grand- father of the female proband had ESRD at the age of 48 years; the mother of the proband started with hemodialysis at the age of 42 years. However, sequence analysis of this missense variant revealed that in some mammals, such as Mus musculus and Rattus norvegicus, histidine in position 4216 is conserved. So, it remains unclear whether this substitution is casual or a very rare sequence change without a pathological manifestation.

The putative missense mutation c. $12683 \mathrm{G} \rightarrow \mathrm{C}$ (p.R4228P) in exon 46 was identified in the patient 38 from the hemodialysis center and is probably responsible 


\section{a}

Proband HD2

c.11340_11345deITTACGA

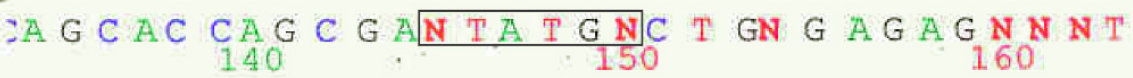

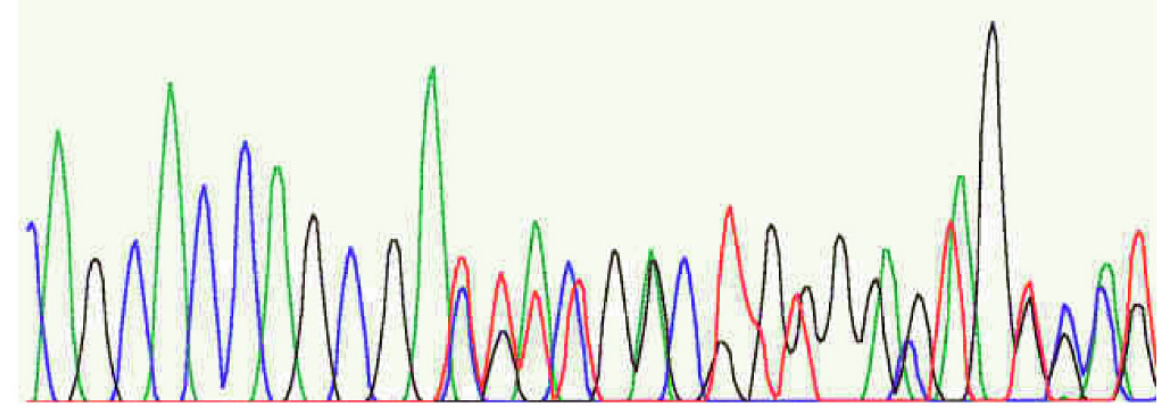

b

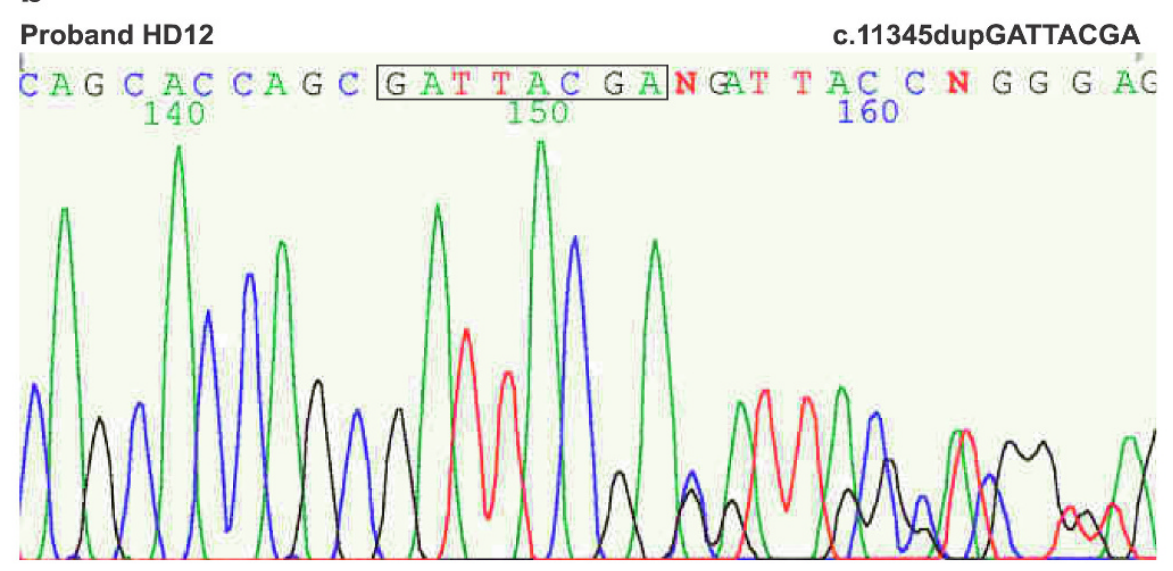

C
Proband 57
c. $11346 \mathrm{C}>\mathrm{T}$

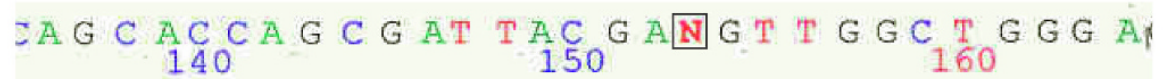

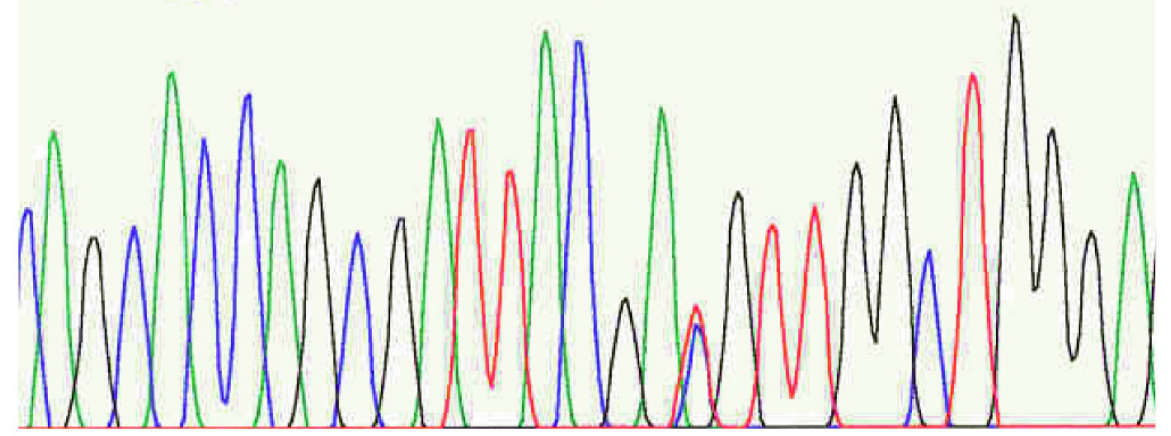

\section{Figure 3}

The area of frequent mutations/polymorphisms in the PKDI gene. a. Sequencing pattern of the exon 40 (forward) in proband HD2 with heterozygous deletion of 6 bases in-frame c.I I340_I I345delTTACGA (p.Y378I_D3782del) of the PKDI gene. b. Sequencing pattern of the exon 40 (forward) in proband HDI 2 with heterozygous duplication of 8 bases c. I I345dupGATTACGA (p.D3782EfsX46) of the PKDI gene. c. Sequencing pattern of the exon 40 (forward) in proband 57 with silent nucleotide change c.II346 C>T (p.A3782A) of the PKDI gene. 
for ADPKD. Arginine (a basic amino acid) was changed to proline (which has an aliphatic side chain unlike the other amino acids). Arginine in this position is conserved in a major part of those species that have been compared (Figure 2).

Polycystin- 1 is a complicated transmembrane protein, whose structure has not been experimentally determined yet. Thus, all reports are based only on a theoretical model of polycystin-1. The model of UniProtKB/Swiss-Prot entry P98161 was used in our report [25].

Five mutations (p.R3753Q, p.Y3781_D3782del, p.D3782EfsX46, p.W3806X, and p.A3875PfsX62) were identified in the 202 amino acid long putative extracellular domain of polycystin-1. This extracellular domain is a part of the polycystin cation channel (PRO13122; AA37114113). This domain is supposed to be post-translationally modified by glycosylation. Additionally, the following putative cytoplasmatic domain, formed by 27 amino acids, is a part of the polycystin cation channel as well (PRO13122; AA37114113). Three mutations (p.Q4011X [29], p.L4019X, p.R4021X [27]) were detected in this intracellular domain of polycystin-1. The $\mathrm{C}$ terminus of polycystin-1 harbors a coiled-coil domain that is involved in the physical interaction with polycystin- 2 . Together, they form functional polycystin complexes in vivo. Three mutations (p.R4228P, p.Q4231X, and p.Q4242X) were identified in this coiled-coil domain.

\section{Conclusion}

In conclusion, twenty putative mutations in the nonduplicated part of the PKD1 gene in 90 Czech individuals were detected. Fifteen of these putative mutations are novel (unique in Czech population). Truncated mutations, detected in $70 \%$ of the cases, were the most frequent mutations.

\section{Competing interests}

The authors declare that they have no competing interests.

\section{Authors' contributions}

JS carried out the molecular genetic studies, majority of mutation screening in PKD1 and participated in the design of the study. JR, MM, and OV collected clinical data and blood samples. SS carried out mutation screening in PKD1. VK carried out sequencing of PKD1 mutations. PL performed tests of occurence of misssense mutations in control set of individuals. MK conceived the study. All authors read and approved the final manuscript.

\section{Acknowledgements}

Contract grant sponsor: IGA MZ CR, Contract grant number: NR9427-3/ 2007.

\section{References}

I. Gabow PA: Polycystic kidney disease: clues to pathogenesis. Kidney Int 1991, 40:989-996.

2. Gabow PA: Autosomal dominant polycystic kidney disease. $N$ Engl J Med I 993, 329:332-342.

3. European Polycystic Kidney Disease Consortium: The polycystic kidney disease I gene encodes a 14 kb transcript and lies within a duplicated region on chromosome 16. Cell 1994, 77:88I-894.

4. International Polycystic Kidney Disease Consortium Polycystic kidney disease: The complete structure of the PKDI gene and its protein. Cell 1995, 81:289-298.

5. The Polycysic Kidney Disease Mutation Database [http:// pkdb.mayo.edu/]

6. Mochizuki T, Wu G, Hayashi T, Xenophontos SL, Veldhuisen B, Saris J], Reynolds DM, Cai Y, Gabow PA, Pierides A, Kimberling WJ, Breuning MH, Deltas CC, Peters DJ, Somlo S: PKD2, a gene for polycystic kidney disease that encodes an integral membrane protein. Science 1996, 272:1339-42.

7. Daoust MC, Reynolds DM, Bichet DG, Somlo S: Evidence for a third genetic locus for autosomal dominant polycystic kidney disease. Genomics 1995, 25:733-736.

8. Torra R, Badenas C, Darnell A, Nicolau C, Volpini V, Revert L, Estivill $X$ : Linkage, clinical features, and prognosis of autosomal dominant polycystic kidney disease types I and 2. J Am Soc Nephrol 1996, 7:2142-2I5I.

9. Hateboer A, van Dijk MA, Bogdanova A, Coto E, Saggar-Malik KA, San Millan JL, Torra R, Breuning M, Ravine D: Comparison of phenotypes of polycystic kidney disease types I and 2. Lancet I999, 353:103-107.

10. Torres VE, Harris PC: Mechanisms of disease: Autosomal dominant and recessive polycystic kidney disease. Nat Clin Pract Nephrol 2006, 2:40-55.

II. Qian F, Germino FJ, Cai Y, Zhang X, Somlo S, Germino GG: PKD I interacts with PKD2 through a probable coiled coil domain. Nat Genet 1997, 16:179-183.

12. Tsiokas L, Kim E, Arnould T, Sukhatme UP, Walz G: Homo- and heterodimeric interactions between the gene products of PKDI and PKD2. Proc Natl Acad Sci USA 1997, 94:6965-6970.

13. Yoder BK, Hou X, Guay-Woodford LM: The polycystic kidney disease proteins, polycystin-I, polycystin-2, polaris, and cystin, are co-localized in renal cilia. J Am Soc Nephrol 2002, 13:2508-2516.

14. Nauli SM, Alenghat FJ, Luo Y, Williams E, Vassilev P, Li X, Elia AE, Lu W, Brown EM, Quinn SJ, Ingber DE, Zhou J: Polycystins I and 2 mediate mechanosensation in the primary cilium of kidney cells. Nat Genet 2003, 33:129-137.

15. Rossetti S, Burton S, Strmecki L, Pon GR, San Millan JL, Zerres K, Barratt TM, Ozen S, Torres VE, Bergstrahl EJ, Winearls CG, Harris PC: The position of the polycystic kidney disease I (PKDI) gene mutation correlates with the severity of renal disease. J Am Soc Nephrol 2002, 1 3: I230- 237.

16. Watnick T, Phakdeekitcharoen B, Johnson A: Mutation detection of PKDI identifies a novel mutation common to three families with aneurysms and/or very-early-onset disease. Am J Hum Genet 1999, 65:1561-I57I.

17. Peral B, Ong ACM, San Millan JL, Gamble V, Rees L, Harris PC: A stable, nonsense mutation associated with a case of infantile onset polycystic kidney disease I (PKDI). Hum Mol Genet 1996, 5:539-542.

18. Hateboer A, Veldhuisen B, Peters DJM, Breuning MH, et al.: Location of mutations within the PKD2 gene influences clinical outcome. Kidney Int 2000, 57:|1444-I45I.

19. Rossetti S, Consugar MB, Chapman AB, Torres VE, Guay-Woodford LM, et al.: Comprehensive molecular diagnostics in autosomal dominant polycystic kidney disease. J Am Soc Nephrol 2007, I8:2143-2160.

20. Ravine D, Gibson RN, Walker RG, Sheffield LJ, Kincaid-Smith P, Danks DM: Evaluation of ultrasonographic diagnostic criteria for autosomal dominant polycystic kidney disease I. Lancet 1994, 343:824-827.

21. Miler SA, Dykes DD, Polesky MF: A simple salting out procedure for extracting DNA from human nucleated cells. Nucl AcidRes 1988, 16:1215. 
22. Perrichot RA, Mercier B, Simom PM, Whebe B, Cledes J, Ferec C: DGGE screening of PKDI gene reveals novel mutations in a large kohort of 146 unrelated patiens. Hum Genet 1999, 105:231-239.

23. National Center for Biotechnology Information. BLAST [http://www.ncbi.nlm.nih.gov/blast/]

24. BioEdit. Biological sequence alignment editor for Windows 95/98/NT/2000/XP [http://www.mbio.ncsu.edu/BioEdit/ BioEdit.html]

25. UniProtKB/Swiss-Prot entry P98161 [http://expasy.org/uniprot/ P98|6I]

26. Takahashi N, Hiyami K, Kodaira M, Satoh C: An improved method for the detection of genetic variations in DNA with denaturating gradient electrophoresis. Mut Res 1990, 234:61-70.

27. Turco AE, Rossetti S, Bresin E, Corrà $S$, Restagno G, Carbonara A, De Prisco O, Gammaro L, Maschio G, Pignatti PF: Detection of two different nonsense mutations in exon 44 of the PKDI gene in two unrelated Italian families with severe autosomal dominant polycystic kidney disease. Nephrol Dial Transplant 1996, I I(Suppl 6): 10-2

28. Neklasov DW, Solomon CH, Dalton AL, Kuwada SK, Burt RW: Intron 4 mutation in APC gene results in splice defect and attenuated FAPphenotype. Familial Cancer 2004, 3:35-40.

29. Daniells C, Maheshwar M, Lazarou L, Davies F, Coles G, Ravine D: Novel and recurrent mutations in the PKDI gene. Hum Genet 1998, 102:216-220.

30. The Human Gene Mutation Database at the Institute of medical Genetics in Cardiff [http://www.hgmd.cf.ac.uk/acl index.php]

31. Rossetti S, Strmecki L, Gamble V, Burton S, Sneddon V, Peral B, Roy S, Bakkaloglu A, Komel R, Winearls CG, Harris PC: Mutation analysis of the entire PKD I gene: genetic and diagnostic implications. Am J Hum Genet 200I, 68(I):46-63.

32. Peral B, Gamble V, Strong C, Ong AC, Sloane-Stanley J, Zerres K, Winearls CG, Harris PC: Identification of mutatio in the duplicated region of the PKDI gene by a novel approach. Am J Hum Genet 1997, 60:1399-1410.

33. Aguiari G, Savelli S, Garbo M, Bozza A, Augello G, Penolazzi L, De Paoli Vitali E, La Torre C, Cappelli G, Piva R, del Senno L: Novel splicing and missense mutations in autosomal dominant polycystic kidney disease I (PKDI) gene: expression of mutated genes. Hum Mutat 2000, 16(5):444-5.

34. Rossetti S, Chauveau D, Walker D, Saggar-Malik A, Winearls CG, Torres VE, Harris PC: A complete mutation screen of the ADPKD genes by DHPLC. Kidney Int 2002, 6I(5): I588-99.

35. Perrichot R, Mercier B, Carre A, Cledes J, Ferec C: Identification of 3 novel mutations (Y4236X, Q3820X, $11745+2$ ins3) in autosomal dominant polycystic kidney disease I gene (PKDI). Hum Mutat 2000, I5:582.

36. Rosseti S, Bresin E, Restagno G, Carbonara A, Corrà S, De Prisco O, Pignatti PF, Turco AE: Autosomal dominant polycystc kidney disaese (ADPKD) in an Italian family carrying a novel nonsense mutation and two missense changes in exons 44 and 45 of the PKDI gene. Am J Med Genet 1996, 65: I55-I59.

37. Vouk K, Strmecki L, Stekrova J, Reiterova J, Bidovec M, Hudler P, Kenig A, Jereb S, Zupanic-Pajnic I, Balazic J, Haarpaintner G, Leskovar B, Adamlje A, Skoflic A, Dovc R, Hojs R, Komel R: PKDI and PKD2 mutations in Slovenian families with autosomal dominant polycystic kidney disease. BMC Med Genet 2006, 7:6.

38. Garcia-Gonzalez MA, Jones JG, Allen SK, Palatucci CM, Batish SD, Seltzer WK, Lan Z, Allen E, Qian F, Lens XM, Pei Y, Germino GG, Watnick TJ: Evaluating the clinical utility of a molecular genetic test for polycystic kidney disease. Mol Genet Metab 2007, 92:160-7.

39. Badenas C, Torra R, San Millán JL, Lucero L, Milà M, Estivill X, Darnell A: Mutational analysis within the 3'region of the PKDI gene. Kidney International 1999, 55: | 225-1233.

40. Peral B, San Millán JL, Ong AC, Gamble V, Ward CJ, Strong C, Harris PC: Screening the 3 ' region of the polycystic kidney disease I (PKDI) gene reveals six novel mutations. Am J Hum Genet 1996, 58(I):86-96.

\section{Pre-publication history}

The pre-publication history for this paper can be accessed here: http://www.biomedcentral.com/1471-2350/10/78/prepub
Publish with Bio Med Central and every scientist can read your work free of charge

"BioMed Central will be the most significant development for disseminating the results of biomedical research in our lifetime. "

Sir Paul Nurse, Cancer Research UK

Your research papers will be:

- available free of charge to the entire biomedical community

- peer reviewed and published immediately upon acceptance

- cited in PubMed and archived on PubMed Central

- yours - you keep the copyright
BioMedcentral 